Article

\title{
Sustainability in FinTechs: An Explanation through Business Model Scalability and Market Valuation
}

\author{
Roberto Moro-Visconti ${ }^{1, *}$, Salvador Cruz Rambaud ${ }^{2}$ (D) and Joaquín López Pascual ${ }^{3} \mathbb{C}$ \\ 1 Department of Economics and Business Management Sciences, Università Cattolica del Sacro Cuore, \\ 20123 Milan, Italy \\ 2 Departamento de Economía y Empresa, Universidad de Almería, 04120 Almería, Spain; scruz@ual.es \\ 3 Departamento de Economía de la Empresa, Universidad Rey Juan Carlos, 28032 Vicálvaro, Spain; \\ joaquin.lopez@urjc.es \\ * Correspondence: roberto.moro@unicatt.it; Tel.: +39-02-72341
}

Received: 15 September 2020; Accepted: 6 December 2020; Published: 10 December 2020

\begin{abstract}
Framework: Financial Technology (FinTech) is an industry composed of diversified firms that combine financial services with innovative technologies. The research question and main goal are attempting to answer whether they are more similar to traditional banks or trendy technological firms deploying their innovativeness to favor financial inclusion and sustainability. Justification: Evaluators may wonder if FinTechs follow the typical evaluation patterns of bank/financial intermediaries or those of technological firms. Preliminary empirical evidence shows that the latter interpretation is the one consistent with the stock-market mood. Objective: This study goes beyond the extant literature, analyzing the differences between FinTechs and traditional banks in market valuation, and showing the potential for digital interaction and cross-pollination of complementary business models. Methodology: The differences will be empirically analyzed with the stock market valuation and the multipliers associated with these firms. Results: The main contribution of this paper is that the appraisal approaches of FinTechs follow those of technological startups, having a revenue model much more scalable than that of a typical bank. FinTechs may so provide a solution for sustainable finance with microfinance and crowdfunding among others. FinTechs and traditional banks may eventually converge towards a common market exploiting co-opetition strategies.
\end{abstract}

Keywords: financial innovation; value chains; scalability; digital platforms; financial ecosystem; discounted cash flows; market value; Sustainable Development Goals

\section{Introduction}

The term "FinTech" denotes the firms that combine financial services with innovative technologies offered to financial service providers. As a rule, new participants in the market offer Internet-based and application-oriented products. FinTechs generally attract customers with products and services that are more user-friendly, efficient, transparent, and automated than those currently available. Traditional banks have not yet exhausted the possibilities for improvements along these lines [1-3].

In addition to offering products and services in the banking sector, some FinTechs distribute insurance and other financial instruments or provide third party services.

FinTech is recognized as one of the most critical innovations in the financial industry and is evolving at a rapid speed, driven by the sharing and circular economy, favorable regulation, and information technology. FinTech promises to disrupt and reshape the financial industry by cutting costs, improving the quality of financial services, and creating a more diverse and stabler financial landscape. FinTechs foster technological innovation in financial services that could result in new 
business models, applications, processes, or products with a material effect on financial markets and institutions, and the provision of financial services [4].

The relevance of the link between sustainability, finance, and technology has been evidenced by the COVID-19 pandemic crisis, which has urged all countries to re-think the models traditionally deployed and rely more on technology and sustainability [5].

FinTechs have already started to fill the financial inclusion gap by providing services to the Bottom of the Pyramid unbanked people, enabled by information and communications technologies (ICT) and new business models. The triple-bottom-line impact analysis that considers economic, social, and environmental sustainability is a new, emerging research area [6]. Nevertheless, as FinTech is innovative but inherently unpredictable, customers are still hesitant to adopt and use it, so affecting its growth. Uncertainty is more critical in FinTech than in traditional e-banking because FinTech transactions are more complicated and less predictable [7].

FinTechs are gaining importance and presence in the financial and banking sector, becoming a game-changing, disruptive innovation capable of shaking up traditional financial markets [8].

The playing field of this study is FinTech business models and their variegated sustainability, providing complementary activities to banks that favors the removal of traditional barriers of the financial sector, favoring financial inclusion. This research strand has been recently well-developed [9] by considering FinTech as the key driver for financial inclusion, and sustainable balanced development, as embodied in the UN Sustainable Development Goals that are a set of 17 targets to create a sustainable world by 2030 (https://sdgs.un.org/goals). Their full potential to support these Goals may be realized progressively supporting digital financial transformation. In this context, the valuation of FinTech companies that make projects viable is an essential part of the sustainability process.

The business model of FinTechs is intangible-driven, combining e-finance, internet technologies, social networking, artificial intelligence, blockchains, and big data analytics, and is more scalable than that of traditional banks. These features impact growth opportunities and trendy patterns consistent with Sustainable Development Goals. This phenomenon will be analyzed in Section 2. The main dimensions aforementioned in the definition of FinTechs are displayed in Figure 1.

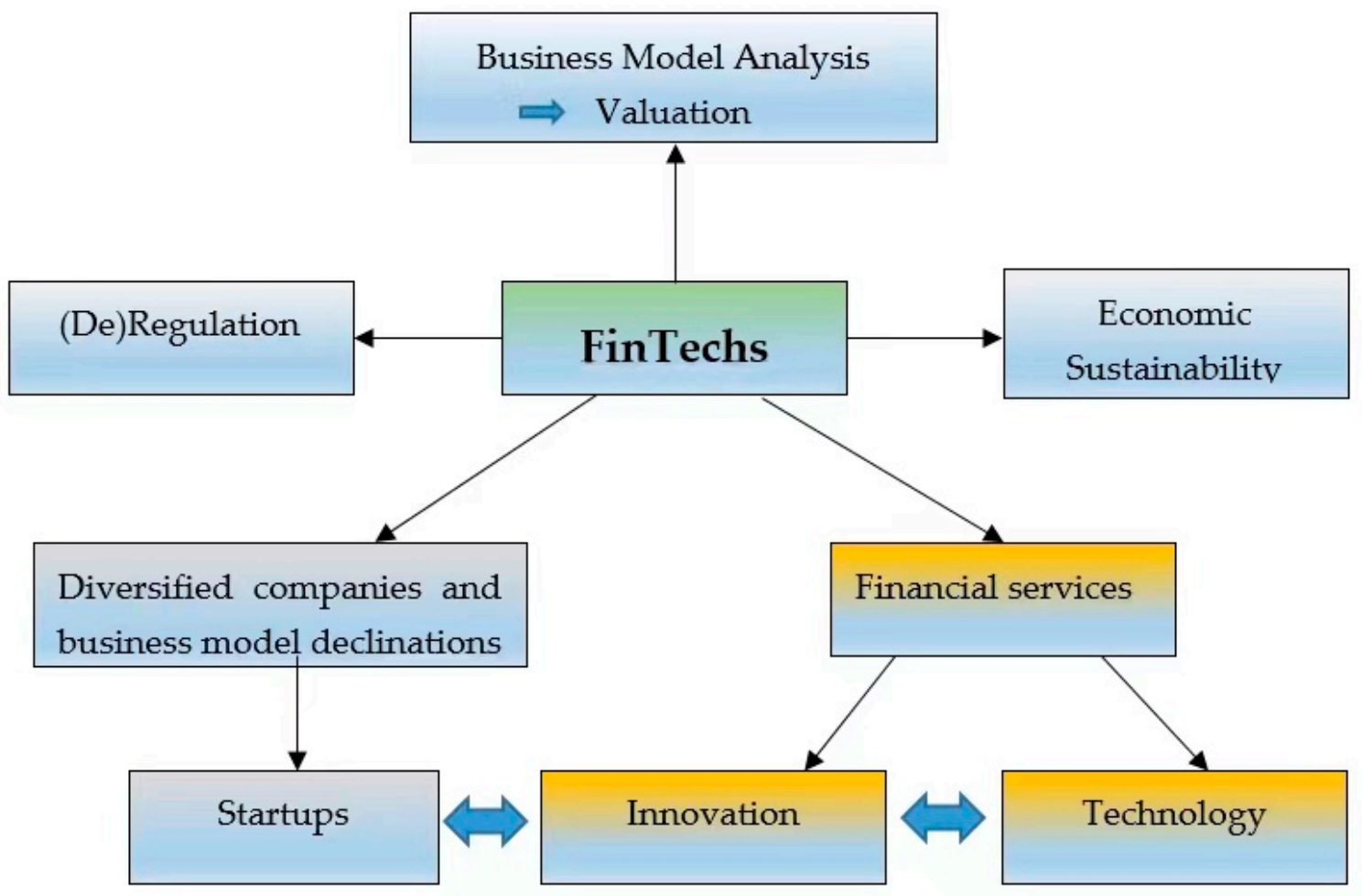

Figure 1. Main dimensions of the FinTech definition. Source: Own elaboration. 
Technological startups include companies operating in the FinTech segment, providing services and financial products with information and communications technologies (ICT). FinTechs reformulate business models, with innovative software and algorithms, value chains based on interactive computer platforms, artificial intelligence, and big data.

Financial services that focus on the transmission of information on digital platforms rely on innovative activities concerning data processing and interpretation in real-time with automated descriptive, prescriptive, and predictive technologies. The design of digital financial markets and systems provided by [9] supports broader access to finance and investment. This means a tremendous potential to transform not only finance but economies and societies, through FinTech, financial inclusion, and sustainable balanced development.

FinTech has become a hot term due to many driven forces, which include technical development, business, and market innovation, cost-saving requirements, and customer demand [10,11]. FinTech refers to a vast and diverse industry that disrupts the financial industry, solving friction points for consumers and businesses to make the overall business more resilient and sustainable.

The banking industry is facing radical transformation and restructuring, as well as a move toward a customer-centric platform that can foster financial inclusion. The competition will increase as new players enter the industry, but the long-term impact is more open. The regulation will decisively influence to what extent FinTechs will enter the industry and who the dominant players will be. The challenge for regulators will be to keep a level playing field that strikes the right balance between fostering innovation and preserving financial stability, and consumer protection [12].

The valuation issues of FinTechs must be adapted to often young companies, given the novelty of the sector, which have all the prerogatives of startups (in terms of expected growth, survival rate, volatility, etc.). The valuation methodologies must consider first the underlying business model. The main internal driver of sustainability is represented by their economic and financial viability that can be detected by examining their business model and current accounts (with reference to economic and financial margins, like EBITDA, net result, operating, and net cash flows). If they are self-sustainable, then they can improve their ecosystem's overall sustainability [13].

According to [14], there are two types of FinTech companies: competitive and collaborative. Competitive FinTechs are larger and mature firms, not necessarily hyper-specialized, aiming to squeeze out new competitors with lower prices. Collaborative FinTechs offer ancillary services to enhance the position of competitors, cooperating with banks [1]. Cooperation is primarily geared to the integration of a FinTech application (product-related cooperation) along the financial intermediation supply chain [15]. A further pattern is be represented by co-opetition, according to which FinTechs and banks both compete and cooperate.

In recent years, considerable progress has been made in the areas of both FinTech and sustainability. However, up to now, these two areas have rarely come together, even if they are the two major drivers of change in the financial sector. There is not a financial institution that is not involved in it. "FinTech is a new financial industry that applies technology to improve financial activities" [16]. In theory, it would be possible to include banks, but this would make it harder to draw a line between traditional market participants and FinTechs.

Moreover, sustainability has grown from a niche preoccupation for business to a mainstream concern. Established FinTech can act as a sustainability catalyst to trigger collaborative innovation between traditional financial and banking institutions [17]. The Sustainable Development Goals offer businesses and stakeholders a common playground on sustainable development [17].

FinTech could help accelerate the development of green and inclusive financial markets and help realign finance to support sustainable development. It offers the prospect of quickening the integration of the financial system with the real economy, which will in turn enhance opportunities for greater decentralization and increased participation.

Based on these premises, the research question of the paper is concerned with the hybrid "Fin + Tech" nature of these innovative firms, wondering if they are more similar to traditional banks 
or trendy technological firms. The business model comparison will be complemented by stock market empirical evidence, limited to a subset of successful listed FinTechs that represent a mighty target for mushrooming startups. Economic sustainability will be investigated as a prerequisite of other sustainability declinations, ranging from the social impact of financial inclusion to the related environmental concerns, consistent with the Sustainable Development Goals.

This paper is organized as follows. Section 2 includes a literature survey, showing the originality of this research question. Section 3 describes the methodology and the research question in further detail, reporting the empirical evidence, with the stock market valuation, and the multipliers of a sample of FinTechs, banks, and technological firms. The implications follow in the subsequent paragraphs. Section 4 synthetizes some interactions between FinTechs and banks, showing differences, and converging patterns. Section 5 contains a discussion, concentrated on asymmetric risk patterns, and Section 6 summarizes and concludes.

\section{Literature Revision}

In this section, we undergo a literature review on the FinTech topic to provide a wide range of approaches from some general concepts [9,18-21], to business model declinations, going from InsurTech [22] to PropTech [23], SupTech [24], RegTech, or services offered (e.g., PayTech - payment systems and processing, P2P loans, open banking, Banking-as-a-Service, etc.) [25], innovative intangibles, like blockchains [26,27], big data [28], or artificial intelligence [29]. FinTech's regulation and supervisory constraints represent a further debated issue [30]. Regulation is softer than that of hyper-vigilated deposit-collecting banks.

A literature revision is propaedeutic to a better-focused framework of the issues analyzed in this study. A comparative analysis of FinTechs versus traditional banks will be considered in particular, consistently with the research question and its multifaceted declinations that also embrace economic sustainability issues.

The long-term viability of FinTechs and their economic sustainability, consistent with their business models, represents an ancillary target of this study. Economic sustainability is a core pillar of a wider interpretation that also embraces social and environmental aspects. Sustainable FinTechs may contribute to the overall stability of the financial system, a well-investigated topic that will be synthetically recalled in the conclusions.

The comparison of the regulatory constraints on fintech versus "traditional" financial firms has been investigated in [31,32], according to which, recent tendencies require the banks to increase investment in FinTech, rethink service distribution channels, especially the business-to-consumers models, increase further standardization of back-office functions, etc. Other authors show that FinTechs ease access to financial services, fostering competition by new players [33]. To survive, incumbent banks must react, face rising competitive pressure, and adopt new strategies.

The FinTech business can also mitigate financial inclusion concerns $[21,34]$ that first of all depends on the economic sustainability issues analyzed in this study, with their social and environmental consequences. Accordingly, FinTech "is the key driver for financial inclusion, which in turn underlies sustainable balanced development, as embodied in the UN Sustainable Development Goals. The full potential of this technological phenomenon to support the Sustainable Development Goals may be realized with a progressive approach to the development of underlying infrastructure to support digital financial transformation" [35]. Additionally, the report "FinTech and Sustainable Development-Assessing the Implications" [35] assesses how the innovations in financial technology could help to align financing with sustainable development. To do this, this report considers the following items:

1. “Unlock greater financial inclusion by reducing the costs for payments and providing better access to capital domestically and internationally;

2. Mobilize domestic savings at a scale that will enable long-term investment directed at the long-term sustainability of the real economy; 
3. Disrupt the provision of financial protection, risk management, risk transfer, and risk diversification for vulnerable and exposed communities, real economy assets and infrastructures, and nature's ecosystems;

4. Collect, analyze and distribute information on the financial system and the real economy for better economic decision-making, regulation, and risk management;

5. Provide financial markets with the level playing field and market integrity needed for long-term real economy investments aligned with the sustainable development agenda".

The "Sustainable Finance and FinTech in Europe" report [36] supports "policymakers in the European Union around the synergies between Sustainable Finance and FinTech, to serve as a starting point for Financial Centers for Sustainability Network global work in the field".

Finally, Figge et al. [37] point out the cost of sustainability capital and the creation of sustainable value by companies, and [38] uses an investment valuation model for sustainable infrastructure systems: Mezzanine debt for water projects.

Focusing on sustainable financial products in the Latin America Banking Industry, a very recent paper on sustainability itself should be highlighted [39]. The purpose of this study is to analyze the extant literature on sustainable financial products (SFP) with a comprehensive understanding of the status quo and research trends.

Hammadi et al. [40] investigate the sustainable performance of FinTechs. A comparative analysis of the business models of FinTechs versus traditional banks is, however, missing (the marketing aspects are investigated in [41]). This study, therefore, fills a gap in the literature, linking the business model analysis with stock market returns.

Other authors interpret FinTech as a platform for the development of sustainable economic growth and as a prompter of the fourth industrial revolution [42]. Traditionally, FinTech has been considered as an expansion of the ordinary or traditional financial industry. The same authors [42] view the industry as having a wider and more inclusive role in transforming all industries toward value creation due to the following arguments. First, FinTech supports all other industries, especially manufacturing, as it induces more production and supply. Contrarily, the effect of the conventional financial industry is limited to the financial subsector and its associated service sectors. Second, the FinTech industry permits a positive linkage between all industries nationwide. Consequently, the industry could be an effective prompter for the sustainable development of the national economy. In effect, under FinTech, financial/monetary-related activities can be executed with higher security through data-validating technologies such as blockchain.

To summarize, FinTech organizations, mainly startups, are reshaping the financial services industry, offering customer-oriented services that combine "speed and flexibility, backed by forward-looking strategies, and cutting-edge business models" [43]. A clear example of these statements can be found in agriculture sustainability [44]. Agriculture is fundamental for food security and primary sustainability issues. However, lack of funding and limited distribution channels are frequent problems. In this context, agriculture's sustainability can be strengthened with innovative services such as FinTech and the digital marketplace. FinTech-enabled digital marketplaces could foster the sustainability of agriculture's business process improving the funding (e.g., crowdfunding) and distribution (e.g., digital payment system) channels. All involved actors (farmers, landowners, investors, and consumers) can then be connected to a digital platform that promotes transparency, empowerment, resourcefulness, and public engagement. Additionally, the University of Cambridge Institute for Sustainability Leadership [45] enumerates significant opportunities for multinationals, financial institutions, and start-ups where FinTech can solve sustainability challenges in the real economy. A case study in Taiwan [46] shows a replicable pattern with geographical scalability elsewhere.

We hypothesize that modularity or scalability is the key factor for developing the banks' future and then creating value [47]. In effect, new banking opportunities must be exploited through higher levels of openness towards third parties and a growing number of modular services bundled together. Another methodology to value FinTech investments is using real options in six business models mainly 
implemented by startups: payment, wealth management, crowdfunding, lending, capital market, and insurance services.

From another point of view, the UK Green Building Council [48] identified 11 value drivers for built environment businesses. A value driver is defined as "Any variable or factor (i.e., a resource, activity or condition) that can be influenced, measured, managed and controlled and, in turn, affects the value of the business by one or more of the following means: reduces risk, increases profitability, leads to future growth in profitability". In this context, sustainable business activities positively interact with many value drivers. Specifically, the main four value drivers proposed by the UKGBC members are highlighted in red in Figure 2. The other complementary drivers impact the business model, shaping the identity and business purpose, and contributing to the overall economic sustainability. FinTechs can be considered here as a complementary catalyzer for scalability, bankability, digital innovation, etc.

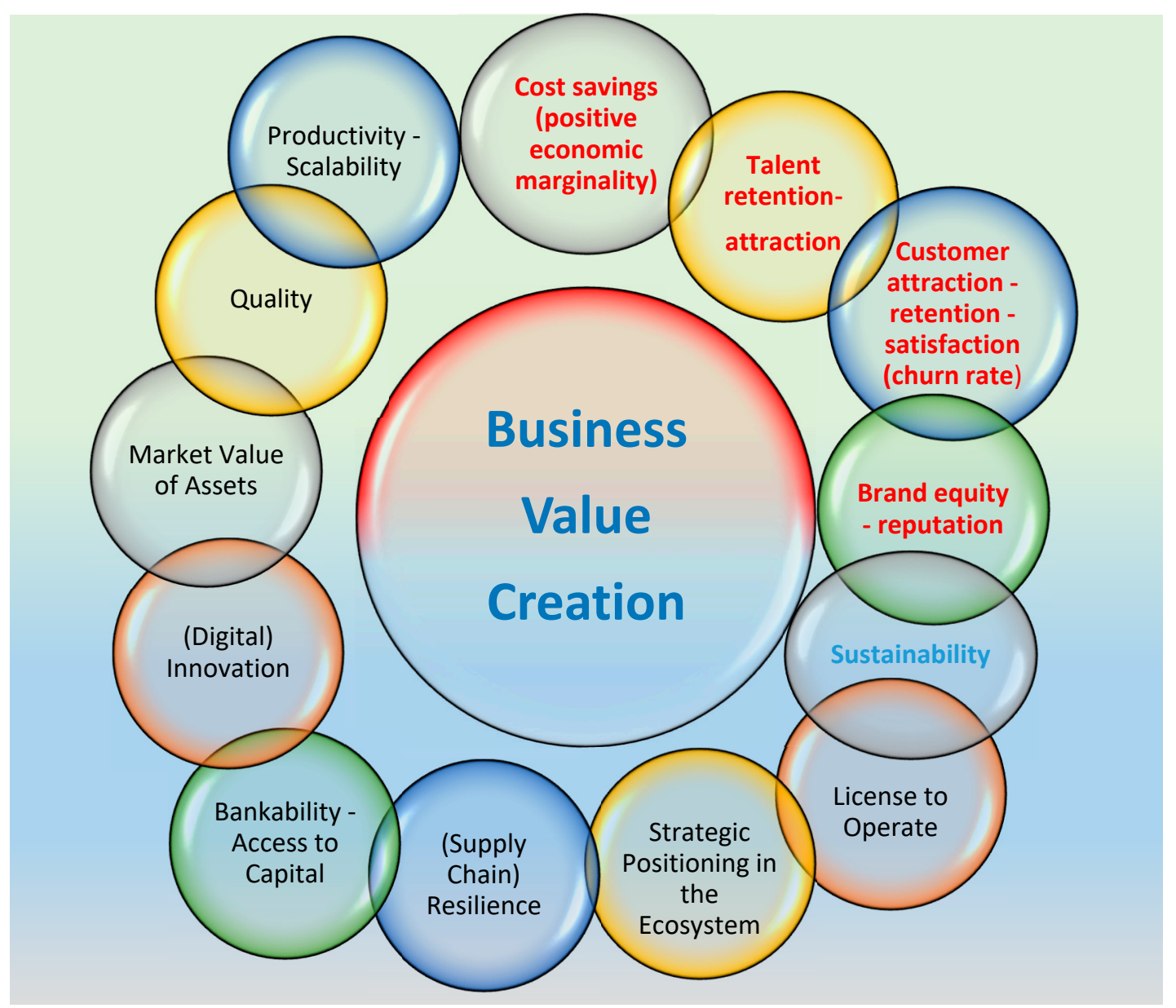

Figure 2. Sustainable Business Activities. Source: own elaboration, adapted from [48].

Given that trillions of dollars will be needed to finance sustainable development, policymakers must assess and consider leveraging opportunities presented by FinTech to contribute to the greening of the global financial system and achieving a sustainable future for humanity [35], consistent with the aforementioned Sustainable Development Goals.

FinTech has the potential to unbundle the banking sector's core functions: clearing and settling payments, performing maturity transformation, sharing risk, validating trust, and allocating capital. FinTech also brings about a new paradigm in which information technology is the driving innovation in the financial industry. FinTech is touted as a game-changing, disruptive innovation capable of shaking up traditional financial markets, being viable to discuss various FinTech business models and investment types [8]. 
The economic sustainability of FinTechs backed by stock market investments has never been comprehensively analyzed. Even the business model comparison between the FinTechs, and either banks or IT companies, has hardly been investigated and represents a further research gap.

This study goes beyond the current literature, analyzing how the differences between FinTechs and traditional banks are reflected in stock market valuation, and showing the potential for digital interaction and cross-pollination of complementary business models. It will be shown that listed FinTechs, like those analyzed in the panel (see Table 3), represent a template and a target for mighty startups that show a strong technological component, and act as digital disruptors in a conservative financial market presided over by established incumbents. The literature concerning the economic sustainability of the FinTechs and its ongoing integration with the banks can, therefore, be expanded, incorporating the main findings of this study.

\section{Methodology and Empirical Evidence}

The appraisal methodology may conveniently start from a synthetic recap of the main evaluation approaches traditionally used for startups, banks, and technological firms that may be adapted to FinTechs.

A comparison of the primary evaluation criteria in traditional (non-financial) firms [49], high-tech firms (startups), and banks/financial intermediaries is reported in Table 1. The correlation with high tech firms and banks seems a useful tool to assess the overall sustainability of FinTechs and their contribution to making the overall financial ecosystem more resilient and inclusive. Internal sustainability (i.e., self-economic-financial viability) is crucial in the confrontation with adjacent firms that populate the same ecosystem. FinTechs are sustainable if they replicate "survival patterns" that resemble those of other technological startups. They also need to interact with banks, sharing their clients.

In an equity valuation theory and practice, there are generally two valuation approaches-discounted cash flows (DCF) and comparables [50].

Table 1. Comparison of the main evaluation approaches of traditional firms, technological startups, and banks. Source: Own elaboration.

\begin{tabular}{ccc}
\hline Traditional Firm [51] & $\begin{array}{c}\text { Technological Startup/Internet } \\
\text { Company [52] }\end{array}$ & Bank (Financial Intermediary) [53] \\
\hline Balance-sheet based & Venture capital method [54,55] & $\begin{array}{c}\text { Expected dividends per share/Dividend } \\
\text { discount models }\end{array}$ \\
Income & Binomial trees/Real option model [56,57] & $\begin{array}{c}\text { Adjusted book value of equity (to proxy } \\
\text { market value) }\end{array}$ \\
Mixed capital-income & Net asset value & Excess return models \\
\hline \multicolumn{3}{c}{ Financial (Discounted Cash Flows-DCF) } \\
\hline \multicolumn{2}{c}{ Market multiples (comparable firms) } \\
\hline
\end{tabular}

Banking and financial activities [58] follow peculiar valuation patterns which often concentrate on parameters like adjusted equity or dividends. These parameters are, however, not particularly meaningful with FinTechs, especially if they are in the startup phase [59].

If the FinTech activity is developed within a banking group by a captive company, it acts as a catalyzer of (traditional) banking activity. In this case, what mostly matters is not the value of the FinTech as a stand-alone reality, but rather its contribution to the incremental marginality of the (traditional) banking group.

FinTechs naturally tend to cooperate with banks, as in most cases they share the same customers, presiding over contiguous segments of the financial supply and value chain. Product-related FinTech-bank cooperation is primarily originated by the integration of original FinTech applications in a wider business model. 
Demyanova [60] considers several methodologies that, in most cases, are rarely applicable to FinTechs. For example, the liquidation value or book value method is not consistent with the innovative nature of startups that become valueless if wound up and derive most of their potential value from intangible assets with little if any collateral value. The Berkus method (five factors of success: idea, technology, employees, market-entry, and the start of sales) appears too undetermined, and real options may be embedded in the estimate of future cash flows with multiple scenarios.

As anticipated, among the main evaluation methodologies, the following are the most relevant:

1. Financial approach (discounted cash flows or DCF).

2. Market comparables.

The financial approach is based on the principle that the market value of the company is equal to the discounted value of the cash flows that the company can generate ("cash is king"). The determination of the cash flows is essential in the application of the approach, as is the consistency of the discount rates adopted in the denominator of the Discounted Cash Flows (DCF) metrics, represented by the cost of capital. The doctrine (especially the Anglo-Saxon one) believes that the financial approach is the "ideal" solution for estimating the market value for limited periods. It is not possible to make reliable estimates of cash flows for longer periods. The conceptually correct methods are those based on cash flow discounting. However, other methods-even though they are conceptually incorrect—continue to be used frequently [51].

The Venture Capital Method is described in the IPEV valuation guidelines [54] that refer to the Option Pricing Method in a scenario analysis (par. 5.11.): for certain early-stage investments, option pricing models are deemed by some to provide a reliable indication of Fair Value where a limited number of discrete outcomes can be expected. This framework is consistent with FinTech startups.

Real options incorporate flexibility and scalable growth opportunities in the business model estimation, so reflecting sustainability concerns. They are consistent with binomial trees probabilistic forecasting and are routinely used in the appraisal of technological firms. Real options can be used in FinTech investment decisions [56,57]. This can be justified because financial institutions may opt to take an immediate investment or wait for the aforementioned investment options based on the volatility and duration of the involved FinTechs. Real options, specifically the option to wait or to quickly expand a scalable product, make sense when investing in venture capital and startups, particularly in internet-related companies such as FinTechs. The appropriate starting time of a novel business is affected by volatility concerns that could undermine its strategic assumptions. Lee et al. [8] state that "real option valuation can be used to develop traditional financial institutions' FinTech projects". Many projects are experimental and are developed in highly dynamic technical, economic, and regulatory environments that require timely flexibility and adaptation. They are so consistent with a real option representation that incorporates resilience and captures uncertainty potential.

Moreover, the classic Net Present Value (NPV) methodology ignores the flexibility of the project which, therefore, is undervalued. On the other hand, the lack of reliable market data makes the use of options difficult. However, real options incorporate flexibility and growth opportunities in the business model forecasting. Consequently, the options to wait, expand, abandon, and contract out make full sense in the context of FinTechs. Finally, they are consistent with binomial trees probabilistic (stochastic) forecasting and are routinely used in the appraisal of technological firms, providing a more intuitive decision tool to decision-makers.

Apart from [56], further literature supports these well-known statements. See, for instance, the Venture Capital Method, described in [54], where the IPEV guidelines refer to option pricing method in a scenario analysis (par. 5.11): for certain early-stage investments, option pricing could provide a reliable indication of fair value where a limited number of discrete outcomes can be expected.

Lee et al. [8] provide an example of a bank looking to invest in a P2P lending FinTech project, by using a binomial tree to calculate the NPV and the option price. The binomial tree valuation methodology, as stated above, mostly applies to startups that still lack a consolidated track-record. 
Whenever FinTechs that survive Darwinian selection evolve and go public (consistently with the panel selected in Table 3), they tend to incorporate their real options in stabler cash flow forecasting, expressed by DCF metrics or market multipliers. Listed FinTechs like Visa or MasterCard are established firms that represent a template and a mighty target for promising startups.

The market (empirical) approach identifies how much investors are paying for similar investments. In practice, an examination of the prices used in negotiations with companies in the same sector leads to average parameters like those represented in Table 3.

The empirical evidence is based on the stock market trend of a sample of FinTechs, compared to an industry benchmark of banks or technological firms. Further insights are given by the metrics of market multipliers of a sample of firms belonging to these three industries.

\subsection{The Stock Market Value of a Sample of FinTechs and Banks}

FinTechs have a hybrid business model, as they operate in the financial (banking) sector deploying their technological attitudes. Evaluators may, therefore, wonder if they follow the typical evaluation patterns of bank/financial intermediaries or those of technological firms. Preliminary empirical evidence-reported below-shows that the latter interpretation is the one consistent with the stock-market mood.

These empirical findings are important for the assessment of the best evaluation criteria. Figure 3 (with data sourced from Bloomberg) contains the comparative stock market price (from 1 August 2015 to 30 June 2020) of:

(a) IFINXNT-Indxx Global FinTech Thematic Index (source: Bloomberg elaboration from public data).

(b) MXW00BK-MSCI World Banks Weighted Equity Index (large and mid-cap stocks across 23 Developed Markets (DM) countries and 26 Emerging Markets (EM) countries) (source: Morgan Stanley elaboration from public data).

(c) MXW00IT-MSCI World (ex-Australia) Information Technology (IT) Index—(source: Morgan Stanley elaboration from public data).

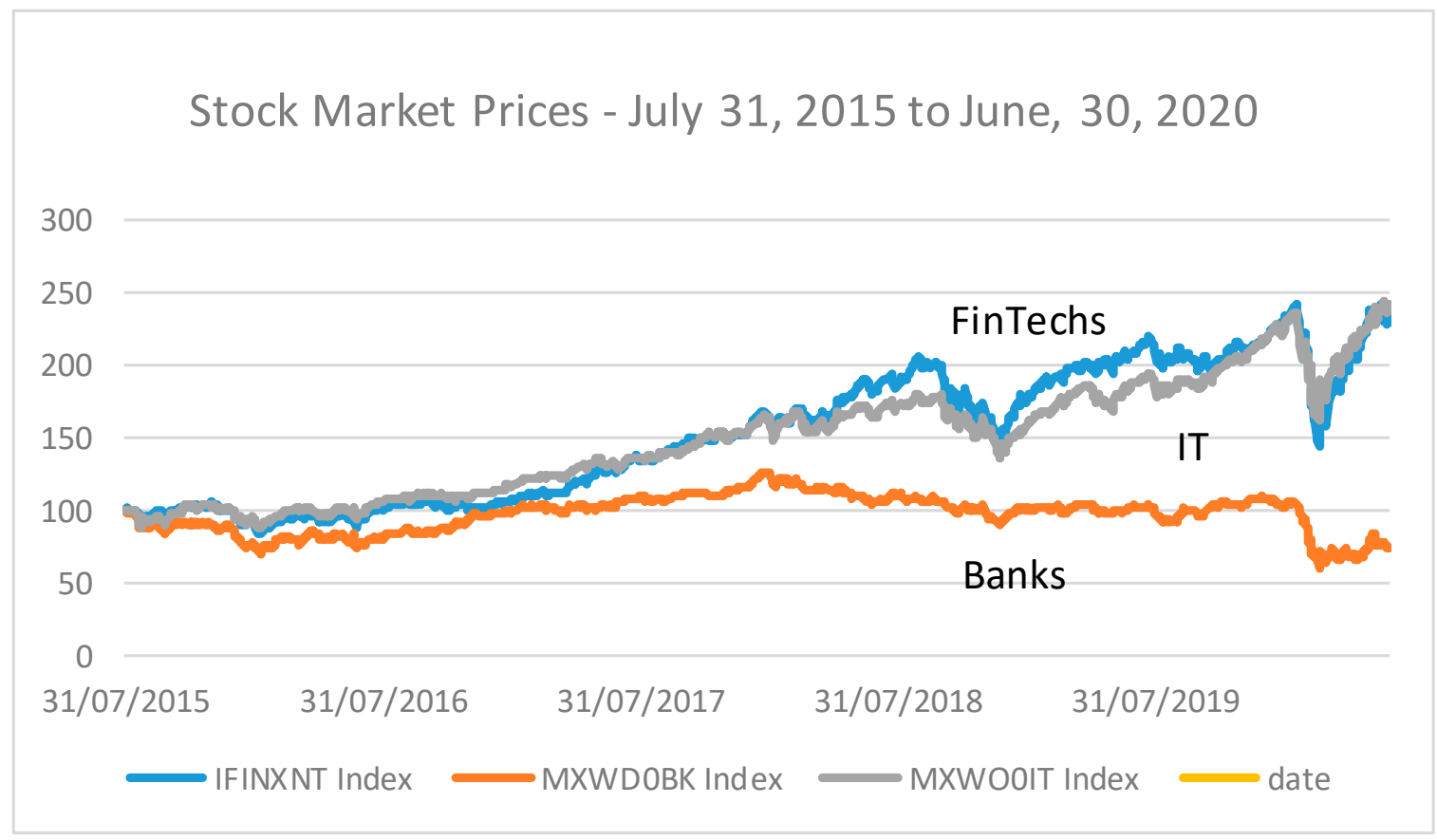

Figure 3. FinTech versus technological and banking Stock Market index. Source: Own elaboration. 
From the input stock market data, it is possible to get the correlation matrix in Table 2, also indicating the volatility (standard deviation).

Table 2. Correlation matrix and volatility. Source: Own elaboration.

\begin{tabular}{lccc}
\hline & FinTechs & Banks & Information Technology \\
\hline FinTechs & 1.0000 & - & - \\
Banks & 0.3441 & 1.0000 & - \\
Information Technology & 0.9774 & 0.2895 & 1.0000 \\
Standard deviation & 45.1167 & 12.9262 & 39.1932 \\
\hline
\end{tabular}

Despite the young age of FinTechs, many of these firms are experiencing significantly faster growth than their traditional financial services peers. This reflects in their performance tracked by the Indxx Global FinTech Thematic Index, the underlying index for the Global X FinTech ETF (FINX), relative to the Financial Select Sector Index.

The Indxx Global FinTech Thematic Index (https://www.indxx.com/indxx-global-FinTech-themati c-index-tr) is designed to track the performance of companies listed in developed markets that are offering technology-driven financial services which are disrupting existing business models in the financial services and banking sectors.

FinTechs are slightly more volatile than IT firms and much more volatile than established banks. This finding is consistent with their belonging to a growing industry, compared to a mature sector. Whereas the correlation coefficient (indicating the standardized covariance) with IT firms is close to its theoretical upper limit $(+1)$, there is room for diversification for those who invest in FinTechs and banks or, even more, in banks and IT firms. This finding roughly indicates that the convergence of FinTech and banking business models is still not discounted by the stock market.

FinTechs' higher volatility (compared to banks) has been reflected in March 2020 in a much deeper fall, followed by a more sustained recovery, incorporating the digital resilience typical of most technological firms. Whereas FinTechs and technology stocks have fully recovered the negative peak of 23 March 2020, banks (as of 30 June 2020) were still some 25\% below their pre-COVID-19 prices.

The data considered in this analysis cover the last five years, from the inception of the FinTech index to the first semester of 2020. This period of historically low interest rates has sustained the overall stock market performance that, however, needs to be selective and able to discriminate between trendy industries and more mature sectors.

\subsection{Market Multipliers}

Market multipliers provide some ancillary interpretation of the Fintech-banks comparison, and are extrapolated and re-elaborated from public data collected in the Bloomberg and Morgan Stanley dataset, and represent a sub-sample of seven FinTechs, compared to five banks and three Information Technology firms. This pilot sample is limited to the biggest FinTechs, banks, and IT firms and represents just an analytical interpretation that backs the more comprehensive market indices examined in Section 3.1. A more detailed analysis of market comparables goes beyond the introductory scope of this comparison with stock market data and may be conducted referring to the quoted Bloomberg source or other specialized data providers (e.g., Eikon-Datastream). Econometric modeling with factor modeling of expected market prices may also represent a further investigation pattern.

These indices are important because they allow for a synthetic comparison of the main FinTechs with Banks and IT firms, showing that FinTechs and IT firms have similar stock market trends. Such a comparison would be much more difficult considering several firms (to be put inside the same graph ... ). Table 3 is, therefore, complementary to Figure 3 since multipliers give a further interpretation that supports market prices. 
Table 3. Market multipliers of a sample of FinTechs, banks, and IT firms. Source: Own elaboration.

\begin{tabular}{|c|c|c|c|c|c|c|c|c|c|c|c|}
\hline Firms & Price/Sales & $\begin{array}{l}\text { Price/Earnings } \\
\text { (P/E) }\end{array}$ & $\begin{array}{c}\text { Price/(Free) } \\
\text { Cash Flow }\end{array}$ & $\begin{array}{l}\text { Price/Book } \\
\text { Value }\end{array}$ & $\begin{array}{l}\text { Enterprise } \\
\text { Value/Sales }\end{array}$ & $\begin{array}{c}\text { Enterprise } \\
\text { Value/EBITDA }\end{array}$ & $\begin{array}{c}\text { Enterprise } \\
\text { Value/EBIT }\end{array}$ & Goodwill & $\begin{array}{c}\text { Weighted } \\
\text { Average Cost of } \\
\text { Capital (WACC) }\end{array}$ & $\begin{array}{l}\text { Enterprise } \\
\text { Value-EV }\end{array}$ & $\begin{array}{c}\text { Unlevered } \\
\text { Beta }\end{array}$ \\
\hline & & & & & & & & USD/000 & & USD/000 & \\
\hline \multicolumn{12}{|l|}{ FinTechs } \\
\hline \multicolumn{12}{|l|}{ Adyen NV } \\
\hline FY 2018 & 8.47 & 106.75 & 37.54 & 24.11 & 7.74 & 70.31 & 73.86 & $12,793,400$ & 28.60 & $12,793,056$ & n.a. \\
\hline FY 2019 & 8.18 & 106.56 & 42.26 & 25.31 & 7.63 & 72.60 & 78.90 & $20,277,827$ & 13.85 & $20,157,283$ & n.a. \\
\hline $27 / 5 / 2020$ & 12.21 & 158.81 & 63.16 & 37.74 & 11.75 & 111.72 & 121.43 & $31,206,358$ & 10.83 & $31,206,358$ & 0.88 \\
\hline \multicolumn{12}{|c|}{ Fidelity National Inf. Serv. Inc. } \\
\hline FY 2018 & 3.99 & 30.76 & 18.03 & 3.29 & 4.97 & 14.55 & 28.72 & $41,872,894$ & 10.22 & $41,872,922$ & 0.35 \\
\hline FY 2019 & 5.99 & 56.76 & 28.01 & 1.76 & 10.18 & 29.56 & 106.13 & $105,181,260$ & 7.62 & $105,264,756$ & 0.57 \\
\hline $27 / 5 / 2020$ & 6.09 & 57.43 & 28.99 & 1.71 & 9.12 & 26.80 & 135.95 & $103,590,099$ & 8.91 & $103,590,099$ & n.a. \\
\hline \multicolumn{12}{|l|}{ Fiserv Inc. } \\
\hline FY 2018 & 5.12 & 30.07 & 25.00 & 12.58 & 5.91 & 14.96 & 19.62 & $34,388,825$ & 9.88 & $34,827,617$ & 0.15 \\
\hline FY 2019 & 5.81 & 38.11 & 28.56 & 1.38 & 6.77 & 20.23 & 42.31 & $69,011,775$ & 7.40 & $102,243,259$ & 0.84 \\
\hline $27 / 5 / 2020$ & 5.11 & 40.05 & 27.25 & 2.23 & 7.49 & 22.18 & 49.99 & $93,231,528$ & 9.15 & $93,231,528$ & 0.67 \\
\hline \multicolumn{12}{|l|}{ Intuit Inc. } \\
\hline FY 2018 & 8.68 & 40.06 & 26.30 & 18.76 & 8.55 & 28.43 & 33.04 & $51,541,732$ & 11.05 & $51,127,591$ & 1.69 \\
\hline FY 2019 & 10.63 & 46.99 & 33.24 & 19.25 & 10.30 & 33.60 & 37.67 & $69,846,516$ & 10.01 & $69,586,783$ & 0.46 \\
\hline $27 / 5 / 2020$ & 10.74 & 55.56 & 39.36 & 15.52 & 10.25 & 38.78 & 45.35 & $70,281,672$ & 10.18 & $70,281,672$ & 1.10 \\
\hline \multicolumn{12}{|l|}{ Mastercard Inc. } \\
\hline FY 2018 & 13.14 & 25.35 & 33.33 & 36.05 & 12.88 & 24.87 & 26.44 & $192,548,150$ & 11.67 & $192,886,660$ & 0.44 \\
\hline FY 2019 & 17.99 & 38.46 & 39.13 & 51.02 & 17.91 & 29.40 & 31.22 & $302,391,130$ & 8.96 & $302,974,610$ & 0.42 \\
\hline $27 / 5 / 2020$ & 18.04 & 37.76 & 37.12 & 56.42 & 18.02 & 29.77 & 31.71 & $306,346,558$ & 10.41 & $306,346,558$ & 0.43 \\
\hline \multicolumn{12}{|l|}{ PayPal Holdings Inc. } \\
\hline FY 2018 & 6.44 & 49.13 & 21.37 & 6.42 & 5.93 & 30.85 & 41.76 & $91,610,660$ & 12.47 & $91,947,020$ & 2.53 \\
\hline FY 2019 & 7.15 & 50.60 & 32.92 & 7.51 & 6.84 & 32.34 & 44.32 & $121,638,410$ & 9.21 & $121,767,397$ & 0.32 \\
\hline $27 / 5 / 2020$ & 9.45 & 72.17 & 39.71 & 10.80 & 9.37 & 46.15 & 65.22 & $171,156,649$ & 9.61 & $171,156,649$ & 0.95 \\
\hline \multicolumn{12}{|l|}{ Visa Inc. } \\
\hline FY 2018 & 14.92 & 32.43 & 25.16 & 11.65 & 16.44 & 24.97 & 26.15 & $338,758,350$ & 9.96 & $340,276,502$ & 3.31 \\
\hline FY 2019 & 14.96 & 31.60 & 28.59 & 11.62 & 15.12 & 22.20 & 23.17 & $347,507,740$ & 9.11 & $349,213,191$ & 0.85 \\
\hline $27 / 5 / 2020$ & 15.98 & 34.55 & 32.06 & 12.93 & 16.17 & 23.55 & 24.77 & $386,248,625$ & 9.23 & $386,248,625$ & 0.73 \\
\hline \multicolumn{12}{|l|}{ Banks } \\
\hline \multicolumn{12}{|c|}{ Bank of America Corp. } \\
\hline FY 2018 & 2.27 & 9.22 & 6.29 & 0.98 & n.a. & n.a. & n.a. & n.a. & 12.13 & n.a. & 0.77 \\
\hline FY 2019 & 2.91 & 12.46 & 5.35 & 1.29 & n.a. & n.a. & n.a. & n.a. & 9.65 & n.a. & 0.64 \\
\hline $27 / 5 / 2020$ & 1.99 & 9.92 & 3.28 & 0.87 & n.a. & n.a. & n.a. & n.a. & 10.79 & n.a. & 0.48 \\
\hline \multicolumn{12}{|l|}{ Citigroup Inc. } \\
\hline FY 2018 & 1.34 & 7.92 & 3.91 & 0.69 & 2.91 & 5.50 & n.a. & $282,880,392$ & 11.95 & $286,715,642$ & 0.64 \\
\hline FY 2019 & 1.74 & 9.33 & n.a. & 0.96 & 3.16 & 5.63 & n.a. & $326,895,286$ & 9.99 & $332,413,364$ & 0.69 \\
\hline $27 / 5 / 2020$ & 1.01 & 9.42 & n.a. & 0.58 & 2.67 & 5.22 & n.a. & $277,572,306$ & 12.61 & $277,572,306$ & 0.42 \\
\hline
\end{tabular}


Table 3. Cont

\begin{tabular}{|c|c|c|c|c|c|c|c|c|c|c|c|}
\hline Firms & Price/Sales & $\begin{array}{l}\text { Price/Earnings } \\
\text { (P/E) }\end{array}$ & $\begin{array}{l}\text { Price/(Free) } \\
\text { Cash Flow }\end{array}$ & $\begin{array}{l}\text { Price/Book } \\
\text { Value }\end{array}$ & $\begin{array}{c}\text { Enterprise } \\
\text { Value/Sales }\end{array}$ & $\begin{array}{c}\text { Enterprise } \\
\text { Value/EBITDA }\end{array}$ & $\begin{array}{c}\text { Enterprise } \\
\text { Value/EBIT }\end{array}$ & Goodwill & $\begin{array}{c}\text { Weighted } \\
\text { Average Cost of } \\
\text { Capital (WACC) }\end{array}$ & $\begin{array}{l}\text { Enterprise } \\
\text { Value-EV }\end{array}$ & $\begin{array}{l}\text { Unlevered } \\
\text { Beta }\end{array}$ \\
\hline \multicolumn{12}{|l|}{ HSBC Holdings PLC } \\
\hline FY 2018 & 2.15 & 13.09 & 80.81 & 1.01 & n.a. & n.a. & n.a. & n.a. & 13.42 & n.a. & 0.52 \\
\hline FY 2019 & 1.89 & 26.17 & 3.76 & 0.98 & n.a. & n.a. & n.a. & n.a. & 9.82 & n.a. & 0.19 \\
\hline $27 / 5 / 2020$ & 1.80 & 26.95 & n.a. & 0.52 & n.a. & n.a. & n.a. & n.a. & 8.06 & n.a. & 0.23 \\
\hline \multicolumn{12}{|c|}{ JPMorgan Chase \& Co } \\
\hline FY 2018 & 2.52 & 10.83 & 23.37 & 1.39 & n.a. & n.a. & n.a. & n.a. & 11.29 & n.a. & 0.42 \\
\hline FY 2019 & 3.15 & 13.67 & 74.28 & 1.83 & n.a. & n.a. & n.a. & n.a. & 8.87 & n.a. & 0.49 \\
\hline $27 / 5 / 2020$ & 2.19 & 10.96 & n.a. & 1.27 & n.a. & n.a. & n.a. & n.a. & 9.97 & n.a. & 0.33 \\
\hline \multicolumn{12}{|l|}{ Wells Fargo \& Co } \\
\hline FY 2018 & 2.19 & 11.33 & 6.13 & 1.22 & n.a. & n.a. & n.a. & n.a. & 10.98 & n.a. & 0.56 \\
\hline FY 2019 & 2.27 & 12.60 & 35.12 & 1.34 & n.a. & n.a. & n.a. & n.a. & 8.49 & n.a. & 0.47 \\
\hline $27 / 5 / 2020$ & 1.14 & 8.44 & 6.50 & 0.67 & n.a. & n.a. & n.a. & n.a. & 9.94 & n.a. & 0.50 \\
\hline \multicolumn{12}{|c|}{ Information Technology } \\
\hline \multicolumn{12}{|l|}{ Apple Inc. } \\
\hline FY 2018 & 4.21 & 19.02 & 17.45 & 10.02 & 3.58 & 11.62 & 13.41 & $950,773,539$ & 9.78 & $967,690,495$ & 1.95 \\
\hline FY 2019 & 3.88 & 18.40 & 17.16 & 10.74 & 3.36 & 11.43 & 13.68 & $874,417,901$ & 9.37 & $891,035,968$ & 1.03 \\
\hline $27 / 5 / 2020$ & 5.26 & 24.85 & 21.14 & 17.46 & 4.85 & 16.49 & 19.75 & $1,298,730,925$ & 9.22 & $1,298,730,925$ & 0.45 \\
\hline \multicolumn{12}{|l|}{ Intel Corp. } \\
\hline FY 2018 & 3.04 & 10.49 & 15.13 & 2.82 & 3.10 & 6.78 & 9.43 & $219,790,000$ & 10.99 & $222,034,000$ & n.a. \\
\hline FY 2019 & 3.69 & 13.89 & 15.67 & 3.32 & 3.75 & 8.18 & 12.25 & $270,204,200$ & 8.95 & $273,809,000$ & 0.75 \\
\hline $27 / 5 / 2020$ & 3.58 & 12.52 & 14.97 & 3.46 & 3.69 & 7.69 & 11.21 & $279,183,560$ & 8.86 & $279,183,560$ & 0.68 \\
\hline \multicolumn{12}{|l|}{ Microsoft Corp. } \\
\hline FY 2018 & 6.88 & 26.90 & 23.54 & 9.15 & 6.44 & 15.15 & 20.17 & $710,768,970$ & 10.91 & & 1.75 \\
\hline FY 2019 & 8.17 & 28.60 & 26.87 & 10.01 & 7.76 & 17.33 & 22.61 & $976,492,280$ & 9.69 & & 0.42 \\
\hline $27 / 5 / 2020$ & 9.99 & 32.05 & 31.94 & 12.04 & 9.54 & 20.02 & 25.35 & $1,323,324,245$ & 8.18 & $1,323,324,245$ & 0.53 \\
\hline
\end{tabular}


The FinTechs listed in Table 3 are mostly active in payments that represent the most mature activity that got first ready for listing, and show the greatest complementarity with banks, even if their stock market behaviour is weakly correlated. Other activities (InsurTech, RegTech, PropTech, SupTech, etc.) are more specific and mostly embodied in promising startups that consider listed FinTechs as an ideal target and whose business model is more distant from that of (traditional) banks. They may, however, inspire further empirical analyses.

Market multipliers are used in relative valuation models, a fundamental analysis valuation method [58] that compares (in relative and not absolute terms) a company's value to that of its competitors or industry peers to assess the firm's financial worth. Relative valuation uses multiples, averages, ratios, and benchmarks to determine a firm's value. Relative valuation models are consistent with the comparison between FinTechs, banks, and IT firms, and have meaningful sustainability implications: stock market appraisal, incorporated in market multipliers, shows how investors perceive the ongoing and perspective value of their investment targets. Firms with good multipliers raise cheaper capital and become more sustainable. The intrinsic self-sustainability of listed FinTechs, appreciated by the investors, improves the strength and resilience of the overall ecosystem, aligning it to the Sustainable Development Goals.

The data reported above are not easy to interpret due to their heterogeneity, even if they show some trendy features which may be summarized as follows:

- The (stock market) price compared to sales (P/sales), expected earnings (P/E), or liquidity ( $\mathrm{P} /$ cash flows) clearly shows that FinTechs command a significant premium over banks (and a smaller premium over the restricted sample of IT firms). This is a strong rationale behind the higher stock market price of FinTechs.

- The Price/Book Value is a proxy of the Tobin Q (the ratio between a physical asset's market value and its replacement value); whenever $\mathrm{P} / \mathrm{BV}>1$, the firm incorporates implicit goodwill, since the market value of equity exceeds the book value. P/BV metrics in FinTechs and IT firms are significantly higher than those that represent banks. Banks often have a $\mathrm{P} / \mathrm{BV}<1$, meaning that there is a "valuation badwill", since the market value is lower than the book value. This occurrence is unusual in listed stocks and shows the negative attitude of investors towards banks.

- Other multipliers compare the Enterprise Value (EV, the market value of the listed firms, including its financial debt) to sales, EBITDA, or EBIT. The ratio EV/EBITDA is particularly meaningful, being used for the market value estimate (EV/EBITDA * expected EBITDA $\approx$ expected EV). Even these multipliers show a meaningful premium for FinTechs, against banks (or even, to a lesser extent, technological firms).

- The goodwill and the EV express the cumulated wealth (and tend to coincide).

- The Weighted Average Cost of Capital (WACC) is the rate used to discount operating cash flows (i.e., liquidity before debt service). The higher the rate, the riskier the firm. FinTechs are on average no riskier than banks and IT firms. This is confirmed also by the unlevered beta, a complementary parameter that measures the market risk of the company (sensitivity to the market index) without the impact of debt.

This pilot example of comparables and multipliers can be extended, using the quoted sources, to a wider set of firms and further research may compare different types of FinTechs (that are still mostly unlisted, especially if they differ from the mainstream payment service function) with commercial or investment banks.

\section{FinTechs Versus Banks (Growth Versus Maturity)}

FinTech has previously grown on its promise to expand access to the financial system by providing services to traditionally unserved or underserved populations. The faster/cheaper/better service models offered by FinTech startups [59] are, however, increasingly disrupting the incumbent banking system. Financial products that traditionally have been the exclusive domain of licensed 
credit institutions-payment services and loans, among others—are now offered by FinTechs [60]. These smaller, more agile companies support a greater diversity of products and providers; they promise greater portability of financial products that are now digitized, built on hybrid and cross-industry business models that allow them to access markets often closed to traditional banks and credit offerors. They also offer greater transparency and improved risk management, at least partly enabled by their ability to get instant customer feedback, and use it to power real-time adjustments in the services they offer [61].

As [8] points out, the traditional financial institutions are investing in FinTech in a variety of ways, including partnering with FinTechs or Technology companies, outsourcing FinTech services, providing venture capital to FinTechs, incubating/accelerating FinTech startups, acquiring/buying FinTechs, and developing internal FinTechs in a continuous search for the sustainability of the financial business. Currently, they have a more pronounced impact in the payments market, where firms have expanded their presence in non-capital-intensive businesses such as cross-border transfers, micropayments, and card payments.

FinTechs (especially those focused on payment systems) and traditional banks operate in the same (financial) market and sometimes share common clients. They are also part of a continuous supply and value chain. It is, therefore, worth wondering why they are different (as shown in Section 4.1), and how they may converge thanks to cross-pollination, and scalable synergies (Section 4.2). As [62] points out, FinTech is an important driver of sustainable development; that is why how financial technology affects sustainable development needs to be urgently identified. The traditional barrier between the developed world and emerging markets is shrinking fast thanks to the rapid digitization and development of the FinTech industry, which is a vital driver for the financial and banking sector to face a challenging future by reducing costs and boosting efficiency. In that way, FinTechs have the potential to mobilize green finance and, for instance, enable poorer people around the world to access innovative clean energy projects.

Additionally, FinTechs can unlock greater financial inclusion for new businesses that will deliver both impact and financial returns; mobilize domestic savings at scale by providing channels or platforms for retail investors to access impact investing opportunities; collect, analyze and distribute information on both financial performance and impact performance for better economic decision-making, regulation and risk management; provide financial markets with the level-playing field and market integrity needed for long-term sustainable investments.

Traditional financial and banking sectors as pure lenders and borrowers are deeply affected by sustainable financial targets that must be achieved by extensive changes and reforms, even concerning financial systems. To give full play to the positive effect of FinTech on sustainable development, countries must reform extensive patterns of economic growth [62].

The valuation of FinTechs is a vital part of this process due to the nature of technological providers of financial services. FinTechs can so be assimilated to innovative startups (or, potentially, more mature companies, such as those considered in the stock market panel).

\subsection{Why Are FinTechs Different?}

FinTechs seem far from the banks even because they have a different business model, as they do not collect deposits and lend money, intermediating credit. The revolutionary changes brought by innovative entrants in the financial services sector have caused severe turbulence in the operational and service activities of the incumbent 'traditional' banking organizations [41].

FinTechs are not hyper-regulated deposit-taking institutions, as they just provide financial services and do not intermediate "money" as a product, and they do not need a supervisory capital like banks. The very fact that FinTechs are not deposit-taking institutions is possibly the main differential factor from banks. Banks are both labor- and capital-intensive, to fuel a business model that still strongly relies on "physical branching" and requires huge compliance-absorbing resources. 
The preliminary conclusion that FinTechs follow the evaluation parameters of technological firms has, however, some caveats which may tentatively be summarized as follows:

(a) If those firms are the purchase target of (much bigger and consolidated) ordinary banks/financial intermediaries, then the valuation criteria of the latter predominate, at least after the acquisition (and especially if they are merged into traditional banks).

(b) The underlying market and business model of maturing FinTechs may become less technological and more "client-based".

(c) Some established criteria used in the evaluation of traditional banks are, however, rarely applicable even in perspective (e.g., consideration of "physical" banking branches as a positive element to be incorporated in the internally generated goodwill).

The business model of a bank is vastly different from that of a typical FinTech and this difference reflects in the balance sheet and in the income and cash flow statement.

The balance sheet of a bank is characterized by a binding structure, due to the presence of the supervisory capital and bank deposits (in the liabilities) and loans to customers (within the assets). The assets and liabilities structure of FinTechs are much "lighter", being represented by net working capital (receivables net of payables) and some capitalized assets (tangible and intangible), against equity and financial debt in the liabilities. The income statement reflects these differences:

- The bank has economic margins represented by the interest rate differential and the net contribution of commissions; interest rate margins are still compressed by historically low market rates (due to the soft monetary policy of central banks, to stimulate the economy), and the long wave of the 2008 recession (with huge amounts on non-performing loans); the pandemic crisis of 2020 may fuel new defaults, in a context where low marginality may not be sufficient to absorb growing credit delinquency.

- The FinTech, as it will be shown in Figure 4, has a more standard EBITDA and EBIT, sourced by the difference between operating revenues (from services) and monetary OPEX (to get to the EBITDA) or comprehensive OPEX, including depreciation and amortization, to determine the EBIT. FinTechs business model is less dependent on labor and capital, although more exposed to technological investments, whose returns are intrinsically risky.

- These balance sheet-based and economic parameters are also reflected in the cash flows (starting from the EBITDA of the FinTechs or the intermediation and interest rate margin of the banks) that are then discounted, in compliance with the main valuation approaches described in paragraph 3.

Other differences reflect on systemic risk. Whereas banks are traditionally a major source of contagion, FinTechs are much more segmented and their probability of default (very frequent in startups) is mitigated by their limited leverage. Startups are typically debt-free, and in this case, operating result (EBIT) or operating cash flow tends to coincide with the net result or the net cash flow, cost of equity replaces WACC, and Enterprise Value equals Equity Value [63].

Banks are strictly connected among themselves, with their clients (borrowers), suppliers (depositors), and regulators, and any concern about their stability may have severe systemic implications. Another feature of many banks is represented by the presence of derivatives in their balance sheet. They are uneasy to record and detect, thereby fueling information asymmetries with disruptive effects, as the 2008 financial crisis has shown.

The different business model has strong scalability implications. Whereas the operating profits (interest and intermediation margin) of a standard bank are difficult to scale up (unless the volumes of loans consistently increase, which is highly risky), the EBITDA/EBIT of a FinTech may follow the blitzscaling trend of many successful technological startups.

The intrinsic scalability depends also on the plasticity of the business model that can be extended to many applications (e.g., RegTech, InsurTech, PropTech, etc.), using synergistic technologies and products (e.g., blockchains, artificial intelligence, big data, digital platforms, cloud computing, etc.). 
FinTechs, therefore, embody real option features (to expand, contract out, defer their business development) which may ignite scalable growth opportunities (incorporated in market valuations).

\section{Interacting Income Statements}
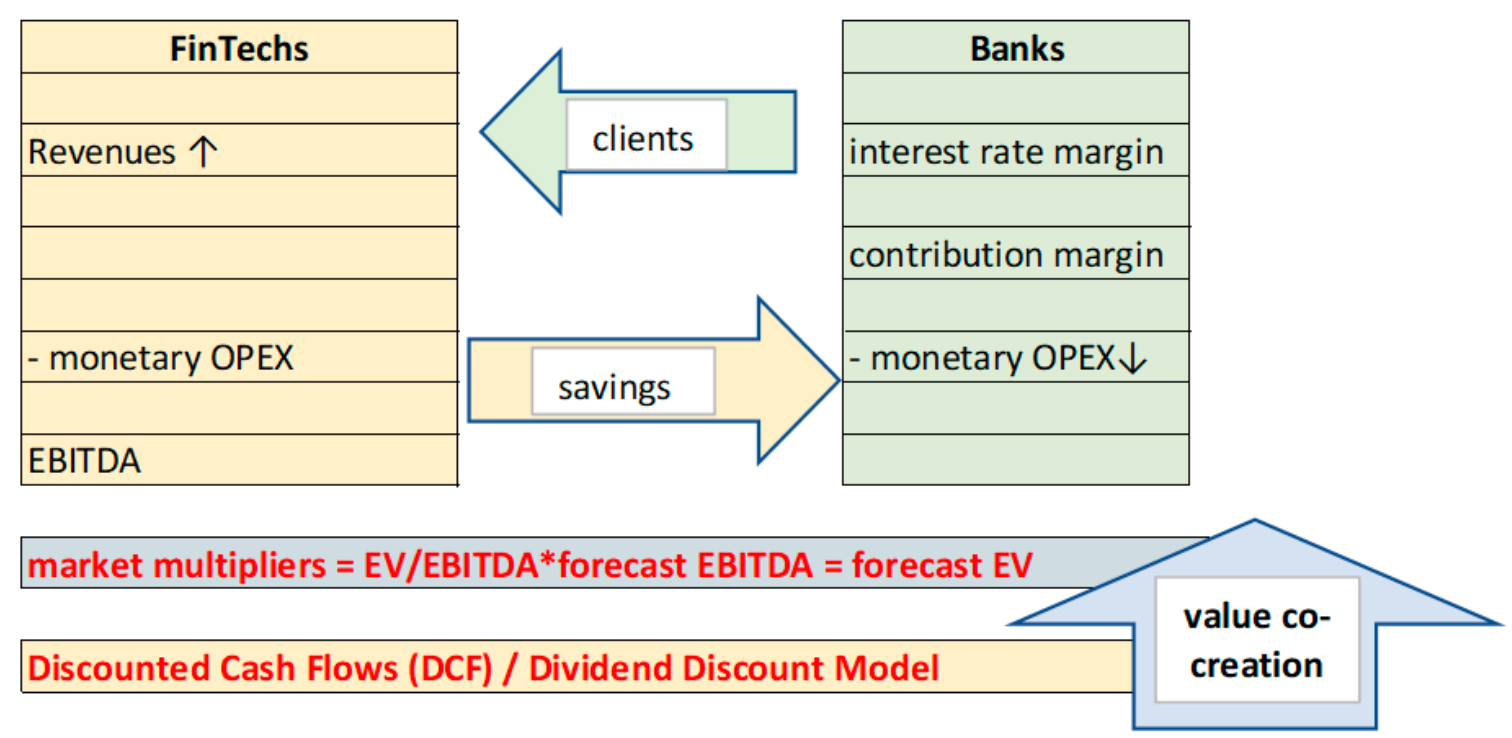

Figure 4. Economic interaction between FinTechs and banks. Source: Own elaboration.

A more analytical explanation of the intrinsic value of FinTechs may be conducted considering classic models like the Economic Value Added, the Residual Income Model, or the Franchise Value Model [64].

The valuation metrics described in paragraph 3, considering the DCF or the market multipliers, record the marginal impact of growth, whose riskier occurrence is, however, to be discounted at a higher rate. According to [65], p. 5, "firms generate cash flows from multiple assets [ ... ] so the discount rates we use should be different for each set of cash flows". The scaling effect which drives the growth rate is difficult to be maintained in the long run, and forecasts of firms with little track-record are intrinsically volatile and so riskier. Technological discontinuity also impacts market risk, threatening the business continuity of incumbent FinTechs. For these very reasons, the discount rate should fairly incorporate this hardly predictable outlook that also reflects potential changes in risk over time. The value creed says rapid growth must eventually peter out.

Traditional banks that operate in a mature market embed in their business model limited growth potential. Mature businesses are typically safer than innovative ones (and that is why scalable growth is discounted at a higher rate of risk), but this may not be the case for old-fashioned banks that front a recession. The market mood, as indicated in Figure 3, Tables 2 and 3, discounts this credit-driven risk that does not appear significantly different from growth (technological) risk.

As shown in Figure 3, Tables 2 and 3, FinTechs and their business models show greater similarity with technological firms. FinTechs are considered as digital disruptors that are usually associated with mobile functionality, simplicity, big data gathering, and processing, accessibility, agility, personalization, and convenience. These technological components are embedded in a business model that resembles that of other Tech ventures in key features as economic scalability, intangible intensity, and prompt flexibility. Hyper-regulated banks with their heavy supervisory capital, high staff costs, and rigid physical branches, are far less related, even if they share similar clients performing complementary activities, especially if considering payment systems. 


\subsection{Cross-Pollination and Scalability}

The different income statements, driven by the respective business model of either the bank or the FinTech, reflect a completely different attitude towards (digital) scalability, as anticipated before.

The interaction with banks can be understood even by comparing their income statements: whereas banks transfer (or share) some of their clients with FinTechs, the latter provide cost-saving solutions that decrease the operational expenditures (OPEX) of banks and improve their resilience. Figure 4 shows the main drivers of this interaction and its impact on valuation, indicating the pivoting role of the income statement in the value generation process, and bringing to the aforementioned main evaluation approaches-market multipliers and DCF.

Figure 4 shows a win-win interaction: if banks share some of their clients with FinTechs, the latter improve their inventive capacity, sharing it back with the banks, and so co-creating value. The clients represent the ultimate "shadow" stakeholder in this triangular relationship and may participate in this value co-creation paradigm with their precious feedbacks which fuels big data and their interpretation and use. This co-opetitive pattern mostly refers to FinTechs involved in the payment segment that is mostly synergic with the traditional banking business.

Banks may internalize this value pattern, buying and merging the FinTech. In this case, the valuation approaches and the business models eventually merge.

FinTechs have a revenue model that is much more scalable than that of a typical bank. Whereas a bank is limited in its growth potential by constraints such as the supervisory capital (a percentage of its loans, weighted for lending risk), huge fixed costs for personnel, and difficult upside in a mature market, FinTechs incorporate a digital potential in an intrinsically scalable business model. Even if FinTechs have a higher marginality potential, they still need the volumes (client base, etc.) and the market caption bound to traditional banks. The positive impact of this cross-pollination on the FinTech EBITDA has a direct implication on the valuation drivers (the market multiplier that incorporates EBITDA and the Discounted Cash Flows influenced by the EBITDA).

\section{Discussion (The Dark Side of Valuation)}

The inductive reasoning of this study explains why the stock market price of FinTechs is so divergent from that of traditional banks. A complementary deductive methodology, starting from the financial market ecosystem, may provide top-down evidence. The flow is summarized in Figure 5.

The business model comparison between FinTechs and banks is a primary methodology to confront diverging market prices, explaining with fundamental analysis and the intrinsic valuation (exemplified by the reference to the market multipliers summarized in Table 3) the difference between the value and the market prices illustrated in Figure 3. Young or complex businesses are difficult to estimate, as shown in The Dark Side of Valuation [66]. Valuation across the business life cycle changes and start-upping FinTechs are quite different from few-but-valuable established ones.

The comparison of this study is somewhat asymmetric, being focused mainly on FinTechs, with little reference to traditional banks. There is, therefore, room for more comprehensive confrontation and integration of the business models, driven by the sharing of similar clients.

Evidence collected so far, and market feedbacks show that listed FinTechs command a premium over traditional banks. However, this consideration does not consider important caveats.

Most FinTechs are still represented by fragile and unlisted startups. Besides, they are mostly unsupervised by Central Bank authorities, especially if they are not involved in deposit collection (that implies a bank license) and lending. Supervision is expensive and time-consuming but reduces the probability of default and provides a parachute, central banks being a lender of last resort to ailing banks. FinTechs may be tempted to pursue circumventive innovation strategies, to get a competitive advantage over hyper-regulated banks.

Stock market prices of FinTechs are sustained by levered expectations of future gains. This bet is intrinsically risky and may be biased by underestimated risk pricing. Market evidence-both in the FinTech index represented in Figure 3 and the subset of listed FinTechs examined in Table 3-is 
meaningful and worth considering, even if it unveils just a side of an intricate issue, concerning a heterogeneous ecosystem of variegated firms that are not fully reflected in stock pricing.
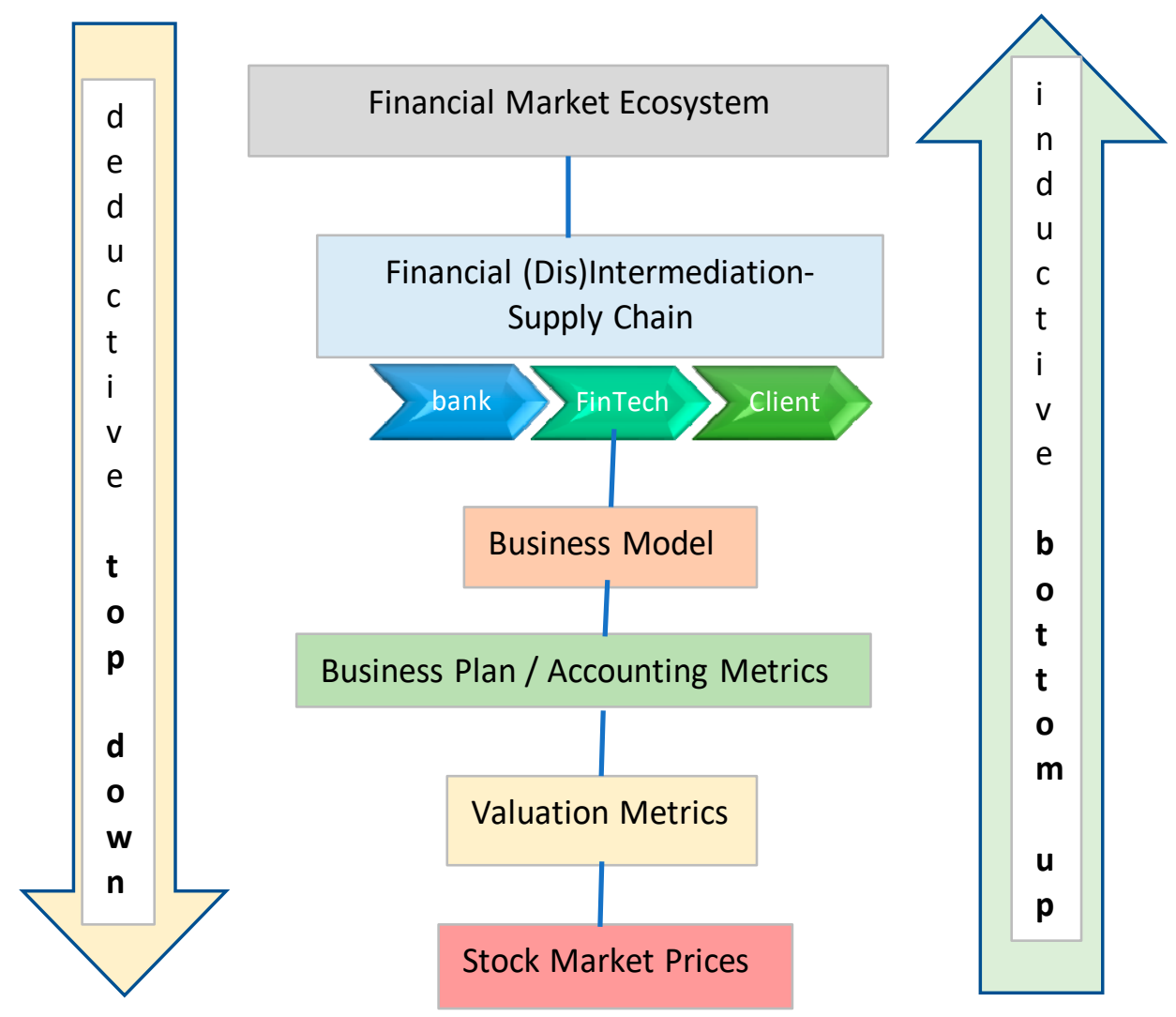

Figure 5. The value-price valuation process, from the financial ecosystem to the Stock Market. Source: Own elaboration.

A further aspect is represented by a well-known property of banks that is almost absent in FinTechs: lending risk. Credit rationing is the limiting by lenders of the supply of additional credit to borrowers who demand funds, even if the latter are willing to pay higher interest rates. It is an example of market imperfection, or market failure, as the price mechanism fails to bring about equilibrium in the market.

Stiglitz and Weiss [67] developed a path-breaking model to illustrate how credit rationing can be an equilibrium feature of the market, in the sense that the rationed borrower would be willing to obtain the funds at an interest rate higher than the one charged by the lender, who will not be willing to lend the extra funds, as the higher rate would imply lower expected profits. It is equilibrium rationing as there exists excess demand for credit at the equilibrium rate of interest.

The reason for that is adverse selection, the situation where the lender is faced with borrowers whose projects imply different risk levels (types), and the type of each borrower is unbeknownst to the lender. The main intuition is that safe borrowers would not be willing to tolerate a high-interest rate, as, with a low probability of default, they will end up paying back a large amount to the lender. Risky types will accept a higher rate because they have a lower chance of a successful project (and typically a higher return if successful), and thus a lower chance of repayment.

The absence of lending risk makes the business model of FinTechs scalable (and so, able to generate high economic and financial margins). Traditional banks face much riskier scalability options: whereas it would be easy for them to expand their borrowing exponentially (approaching billions of unbanked potential customers), they would face marginally growing risk, and higher fixed costs, probably bringing them to negative margins. Bank scalability may, therefore, end up in a boomerang, 
especially before and during recessions, when credit quality rapidly deteriorates. In parallel with the risks of traditional banks, FinTechs may increase some costs and reduce the value to the consumer, introducing new conduct of business risks (different ways of miss-selling and misadvising, not least by providers using insights gained from big data to exploit behavioral biases and fears to sell consumers unsuitable products and services); lead to greater financial exclusion and discrimination through big data analytics and the use of personal information and facilitating new types of fraud and data breaches.

Finally, some risk concerns about the FinTech industry cannot avoid the measurement of systemic risks arising from contagion mechanisms between borrowers, focusing on how the development and the growth of financial technologies can make them sustainable, minimizing their possible negative impacts on consumers and investors. This goal can be achieved through the development of appropriate risk management methods and market valuation.

Risk is a primary component of firm evaluations (being incorporated, for instance, in the cost of capital that represents the denominator of discounted cash flows) and is embedded in stock market prices. It is so unsurprising that banks have largely discounted market prices if compared to FinTechs or other technological firms. Consistently with a major thesis of this study, FinTechs have a risk profile that is vastly different from that of banks, and much more like that of technological startups. They share with tech startups a little history and limited track record, and they strongly rely on growth opportunities, scalability, and real options that are intrinsically volatile, and uncertain. Strong competition, technological disruption (uneasy to foresee), lack of a consolidated client base, low competitive entry barriers in the industry, limitations to geographical scalability due to different regulatory issues, represent further risk concerns.

\section{Conclusions}

The main thesis of this study is that the evaluation of FinTechs follows appraisal approaches that are similar to those of technological startups and differ from those of the (traditional) banks. Even if the underlying industry is represented by bank activities, FinTechs are innovators/facilitators of financial activities and are not personally involved in the borrowing/lending hyper-regulated intermediation business. Due to their nature as technological providers of financial services, FinTechs can so be assimilated to innovative startups.

Empirical evidence shows that stock market prices nowadays reward FinTechs that incorporate steep multiples of earnings and book value if compared to unfashionable banks. Market comparables back this interpretation, although a larger sample of FinTech, IT, and banking firms are desirable and may eventually contribute to a better general understanding of this phenomenon. Reversals of fortune are, however, always possible, as the Roman poet Horace remembers ("many shall be restored that now are fallen and many shall fall that are now in honor"). Additionally, sobriety is the best antidote against irrational exuberance [68] and the legacy of the dot.com bubble of Spring 2000, driven by analysts' distorted valuations [69]. The threat that FinTechs could fall in some speculative bubbles may be softened by watchful cherry-picking, where investors carefully select their investments looking at the fundamentals, without relying too much on mighty multiples that may overstate future expectations.

Furthermore, FinTechs and banks operate in the same financial business (although with different features) and share similar clients. It is also a frequent practice that banks can internalize a FinTech by buying it. FinTechs and traditional banks converge towards a common market, with co-opetition strategies that reduce the conflicts of interest and other governance concerns. This strategic convergence is also catalyzed by the very fact that banks are digitalizing their business models, so reducing their atavistic differences.

M-banking and digital payments represent the most popular FinTech solution and are compliant with contactless pandemic prescriptions. Changes induced by the COVID-19 crises are likely to accelerate existing trends, possibly bringing to a "TechFin" open-banking scenario [70] where unregulated BigTech players (like Amazon, Apple, or Facebook) intermediate data and consumer relationships, using standard interfaces. Though banks can replicate most of what FinTechs can do, 
FinTechs benefit from an uneven playing field since they are less regulated than deposit-taking banks, and may be tempted by circumventive opportunistic behaviours.

It is well known that technology is creating value in financial services. The reasons are many [71]. First, costs have been dramatically cut thanks to technology. For example, branchless customers do not need to spend time or energy going to the bank. Second, revenues are increased because banking becomes 24/7: anytime, anywhere, increasing the velocity of transactions [72]. Third, for the whole industry, the emergence of new operators is normally less regulated at the beginning, softening adoption criticalities but underestimating incubating threats.

This study has also analyzed, as a by-product of the main research question, the sustainability features of FinTechs mainly from an economic perspective that assesses long-term viability, being reflected in market valuations. Economic sustainability is considered here as a prerequisite for further sustainability declinations, embracing social and environmental concerns.

FinTechs promote both sustainable development and green finance. According to [73], we are leaving the world of traditional banking and accepting new business models, such as FinTech, which are more and more involved in supporting the Sustainable Development Goals. Financial technology is also an excellent tool to build sustainable communities and lift poverty, as it promotes responsible consumption and production, fostering gender equality in both developed and developing countries. FinTech itself is environmental-friendly facilitating green finance, reducing asymmetric information for investors, promoting efficiency, valuing nature's assets, and backing sustainable lifestyles inspired by a sharing or circular economy. They may, therefore, provide innovative solutions for sustainable finance: SME microfinance, inclusive ownership, international investments, and digital platform solutions (in particular, crowdfunding and peer-to-peer lending and borrowing).

FinTechs are reshaping the banking industry, proposing innovative technological solutions that foster customer-centricity, creating shared and sustainable value. Their valuation, relative to that of banks, provides an indirect appraisal of FinTech-driven sustainable products and services.

Further research avenues may concentrate on the converging business of FinTechs, banks, and BigTechs [74], driven by digitalization [75], disintermediation, customer centricity, and other centripetal forces that support green finance and sustainable development [76,77]. Digital platforms represent a bridging node (interface) that connects the FinTechs, the banks, and the clients within the financial intermediation ecosystem. This ecosystem can be mathematically interpreted with multilayer network theories and fostered with blockchain validation and artificial intelligence algorithms that represent frontier interdisciplinary research.

Financial stability implications from FinTechs [78], and financial integration among different players are crucial for the sustainability of the financial intermediation ecosystem, and also deserve further interdisciplinary scrutiny. The consequences seem relevant for both the academic and professional fields.

This research is limited first by the lack of consolidated empirical evidence from the still young FinTech industry, and by a yet preliminary consideration of the comparative business models of FinTechs and banks, whose synergies remain underexplored. In particular, the market index considered here is recent and the sample limited to a subset of the potential FinTechs, still largely unlisted.

Another current issue is represented by the Environmental, Social, and Governance (ESG) targets [13] that are increasingly requested by green investors and Social Impact Funds, bearing regulatory implications [79]. Even here, the impact of FinTechs may be substantial, especially to improve financial outreach to the unbanked, opening the door to the global digital economy [80].

The contribution of FinTechs to the overall stability of the financial ecosystem is a further issue that needs additional investigation. FinTechs incorporate financial stability risks that require systematic monitoring [81]. The lack of institutional support for new financial technologies is also an important catalyst for the financial industry destabilization and the formation of financial bubbles [82]. A sustainable financial ecosystem can, however, benefit from the disrupting impact of new technologies on incumbent banks and regulators [83]. 
Finally, as competition develops between FinTechs and established banks, the conservative financial system presided over by incumbent players could become more sophisticated and competitive, fostering financial inclusion. However, it could also become more concentrated, as it is happening with big-tech platforms, generating new risks to financial stability and sustainability that deserve watchful scrutiny from both academics and practitioners.

Despite the small sample used in this preliminary research, this study contributes to the scant empirical literature on FinTechs versus (traditional) banks. This paper also helps revisit the literature on the economic sustainability of FinTechs backed by stock market investments that has never been comprehensively analyzed. Finally, our aim is to continue the research on this "revolutionary" [84] topic by enlarging the sample and collecting data on actual Fintech and (traditional) banks' differences and similarities, outlining their strengths, weaknesses, and convergence patterns.

Author Contributions: Sections 3 and 4 are mainly attributable to R.M.-V.; the other Sections are mainly attributable to S.C.R. and J.L.P. All authors have read and agreed to the published version of the manuscript.

Funding: This research has been equally funded by a research grant from the Università Cattolica del Sacro Cuore, Milan, Italy, and the Spanish Ministry of Economy and Competitiveness (grant number DER2016-76053R).

Conflicts of Interest: The authors declare no conflict of interest.

\section{References}

1. Dorfleitner, G.; Hornuf, L.; Schmitt, M.; Weber, M. FinTech in Germany; Springer: Cham, Switzerland, 2017.

2. EBF. The Digital Transformation of Banks and the Digital Single Market (EBF Discussion Paper Nr. 015782); European Banking Federation: Brussels, Belgium, 2015.

3. Mackenzie, A. The FinTech revolution. Lond. Bus. Sch. Rev. 2015, 26, 50-53.

4. Financial Stability Board, FinTech and Market Structure in Financial Services: Market Developments and Potential Financial Stability Implications, 14 February 2019. Available online: https://www.fsb.org/work-ofthe-fsb/policy-development/additional-policy-areas/monitoring-of-FinTech/ (accessed on 4 December 2020).

5. Macchiavello, E.; Siri, M. Sustainable Finance and FinTech: Can Technology Contribute to Achieving Environmental Goals? A Preliminary Assessment of 'Green FinTech'. European Banking Institute Working Paper Series 2020—No. 71. Available online: https://ssrn.com/abstract=3672989 (accessed on 4 December 2020).

6. Varga, D. Triple-bottom-line impact analysis framework of FinTech companies. Vez. Bp. Manag. Rev. 2018, 49, 24-34. [CrossRef]

7. Ryu, H.-S.; Ko, K.S. Sustainable Development of FinTech: Focused on Uncertainty and Perceived Quality Issues. Sustainability 2020, 12, 7669. [CrossRef]

8. Lee, I.; Shin, Y.J. FinTech: Ecosystem, business models, investment decisions, and challenges. Bus Horiz. 2018, 61, 35-46. [CrossRef]

9. Gai, K.; Qiu, M.; Sun, X. A survey on FinTech. J. Netw. Comput. App. 2018, 103, 262-273. [CrossRef]

10. Gimpel, H.; Rau, D.; Röglinger, M. Understanding FinTech start-ups-A taxonomy of consumer-oriented service offerings. Electron Mark. 2018, 28, 245-264. [CrossRef]

11. Piobbici, F.; Rajola, F.; Frigerio, C. Open Innovation Effectiveness in the Financial Services Sector. In Enterprise Applications, Markets and Services in the Finance Industry; Mehandjiev, N., Saadouni, B., Eds.; Springer: Cham, Switzerland, 2019; Volume 345.

12. Vives, X. Digital disruption in banking. Annu. Rev. Financ. 2019, 11, 243-272. [CrossRef]

13. Sustainability, FinTech and Financial Inclusion. Available online: https://link.springer.com/article/10.1007/s4 0804-020-00183-y (accessed on 4 December 2020).

14. Accenture. FinTech and the Evolving Landscape. 2016. Available online: https://www.accenture.com/us-en/ insightFinTech-evolving-landscape (accessed on 4 December 2020).

15. Philippon, T. The FinTech Opportunity; National Bureau of Economic Research: Cambridge, MA, USA, 2019.

16. Shueffel, P. Taming the Beast: A Scientific Definition of FinTech. J. Innovat. Manag. 2016, 4, 32-54. [CrossRef] 
17. Verhagen, T. Catalysing FinTech for Sustainability. Lessons from Multi-Sector Innovation. A Report of the BEI's FinTech Taskforce. 2017. Available online: https://www.researchgate.net/publication/328345987_Catal ysing_FinTech_for_Sustainability_Lessons_from_multi-sector_innovation_A_report_of_the_BEI $\backslash T 1 \backslash$ textq uoterights_FinTech_Taskforce (accessed on 4 December 2020).

18. Mehrban, S. Towards secure FinTech: A survey, taxonomy, and open research challenges. IEEE Access 2020, 8, 23391-23406. [CrossRef]

19. Razzaque, A.; Hamdan, A. In Role of Financial Technology FinTech: A Survey. In Proceedings of the International Conference on Artificial Intelligence and Computer Vision, Cario, Eygpt, 8-10 April 2020; (AICV2020). Hassanien, A.E., Azar, A., Gaber, T., Oliva, D., Tolba, F., Eds.; Springer: Cham, Switzerland, 2020; p. 1153.

20. Allen, F.; Gu, X.; Jagtiani, J.A. A Survey of FinTech Research and Policy Discussio; FRB of Philadelphia Working Paper; FRB: Washington, DC, USA, 2020; pp. 20-21.

21. Philippon, T. On FinTech and Financial Inclusion. Stern School of Business, Working Paper. 2019. Available online: https://www.bis.org/events/conf190628/philippon.pdf (accessed on 4 December 2020).

22. Wilamowicz, A. The great FinTech disruption: InsurTech. Bank. Financ. Law Rev. 2019, 34, 215-238.

23. Saiz, A. Bricks, mortar, and proptech: The economics of IT in brokerage, space utilization and commercial real estate finance. J. Prop. Invest. Fin. 2020, 38, 327-347. [CrossRef]

24. Lemma, V. FinTech, Regtech and Suptech Towards a New Market Structure; Palgrave Macmillan: Cham, Switzerland, 2020.

25. Agarwal, S.; Zhang, J. FinTech, lending and payment innovation: A review. Asia Pacific J. Fin. Stud. 2020, 49, 353-367. [CrossRef]

26. Cai, C.W. Disruption of financial intermediation by FinTech: A review on crowdfunding and blockchain. Account Fin. 2018, 58, 965-992. [CrossRef]

27. Chen, M.A.; Wu, Q.; Yang, B. How valuable is FinTech innovation? Rev. Financ. Stud. 2019, 32, $2062-2106$. [CrossRef]

28. Ferretti, F. Consumer access to capital in the age of FinTech and big data: The limits of EU law. Maastricht J. Eur. Comp. Law 2018, 25, 476-499. [CrossRef]

29. Jakšič, M.; Marinč, M. Relationship banking and information technology: The role of artificial intelligence and FinTech. Risk Manag. 2019, 21, 1-18. [CrossRef]

30. Magnuson, W. Regulating FinTech. 2018. Available online: https://heinonline.org/HOL/LandingPage?handl e=hein.journals/vanlr71\&div=33\&id=\&page= (accessed on 4 December 2020).

31. Romānova, I.; Kudinska, M. Banking and FinTech: A challenge or opportunity? In Contemporary Issues in Finance: Current Challenges from Across Europe; Emerald Group Publishing Limited: Bingley, UK, 2016; Volume 98, pp. 21-35.

32. Thakor, A.V. FinTech and banking: What do we know? J. Financ. Intermed. 2020, 43, 100833. [CrossRef]

33. Navaretti, G.B.; Calzolari, G.; Mansilla-Fernández, J.M.; Pozzolo, A.F. FinTech and Banking. Friends or Foes? 2018. Available online: https://ssrn.com/abstract=3099337 (accessed on 4 December 2020).

34. Moro-Visconti, R. MicroFinTech: Outreaching Financial Inclusion with Cost-Cutting Innovation. Working Paper. 2019. Available online: https://www.researchgate.net/publication/332818363_MICROFINTEC H_OUTREACHING_FINANCIAL_INCLUSION_WITH_COST-CUTTING_INNOVATION (accessed on 4 December 2020).

35. United Nations Environment Programme. FinTech and Sustainable Development-Assessing the Implications. 2016. Available online: http://unepinquiry.org/wp-content/uploads/2016/12/FinTech_and _Sustainable_Development_Assessing_the_Implications.pdf (accessed on 4 December 2020).

36. Financial Centers for Sustainability (FC4S) and Stockholm Green Digital Finance. Sustainable Finance and FinTech in Europe; Stockholm Green Digital Finance: Stockholm, Sweden, 2019.

37. Figge, F.; Hahn, T. The cost of sustainability capital and the creation of sustainable value by companies. J. Indust. Ecol. 2005, 9, 47-58. [CrossRef]

38. González-Ruiz, J.D.; Arboleda, A.; Botero, S.; Rojo, J. Investment valuation model for sustainable infrastructure systems: Mezzanine debt for water projects. Eng. Constr. Archit. Manag. 2019, 26, 850-884. [CrossRef]

39. Mejia-Escobar, J.C.; González-Ruiz, J.D.; Duque-Grisales, E. Sustainable Financial Products in the Latin America Banking Industry: Current Status and Insights. Sustainability 2020, 12, 5648. [CrossRef] 
40. Hammadi, T.A.; Nobanee, H. FinTech and Sustainability: A Mini-Review. 2019. Available online: https: //ssrn.com/abstract=3500873 (accessed on 4 December 2020).

41. Anand, D.; Mantrala, M. Responding to disruptive business model innovations: The case of traditional banks facing FinTech entrants. J. Bank Financ. Technol. 2019, 3, 19-31. [CrossRef]

42. Shin, Y.J.; Choi, Y. Feasibility of the FinTech industry as an innovation platform for sustainable economic growth in Korea. Sustainability 2019, 11, 5351. [CrossRef]

43. Nicoletti, B. The Future of FinTechs. In Integrating Finance and Technology in Financial Services; Palgrave Studies in Financial Services Technology: Cham, Switzerland, 2017.

44. Anshari, M.; Almunawar, M.N.; Masri, M.; Hamdan, M. Digital marketplace and FinTech to support agriculture sustainability. Energy Procedia 2019, 156, 234-238. [CrossRef]

45. University of Cambridge Institute for Sustainability Leadership (CISL). Catalysing FinTech for Sustainability: Lessons from Multi-Sector Innovation; Cambridge Institute for Sustainability Leadership: Cambridge, UK, 2017.

46. Hung, J.L.; Luo, B. FinTech in Taiwan: A case study of a Bank's strategic planning for an investment in a FinTech company. Finan. Innov. 2016, 2, 1-16. [CrossRef]

47. Omarini, A.E. Banks and FinTechs: How to develop a digital open banking approach for the bank's future. Int. Bus Res. 2018, 11, 23-36. [CrossRef]

48. UK Green Building Council. Capturing the Value of Sustainability: Identifying the Links between Sustainability and Business Value. 2018. Available online: https:/www.worldgbc.org/sites/default/fil es/Capturing-the-Value-of-Sustainability_0.pdf (accessed on 6 October 2020).

49. Pinto, J.E.; Robinson, T.R.; Stowe, J.D. Equity valuation: A survey of professional practice. Rev. Financ. Econ. 2019, 37, 219-233. [CrossRef]

50. Mirzayev, E. Discounted Cash Flows vs. Comparables. 2020. Available online: https://www.investopedia.c om/articles/professionals/072915/dcf-vs-comparables-which-one-use.asp (accessed on 4 December 2020).

51. Fernández, P. Valuation using multiples. In How do Analysts Reach Their Conclusions? IESE Business School: Madrid, Spain, 2001.

52. Moro-Visconti, R. The Valuation of Digital Intangibles. Technology, Marketing and Internet; Palgrave Macmillan: Cham, Switzerland, 2020.

53. Damodaran, A. Valuing Financial Service Firms. 2009. Available online: http://people.stern.nyu.edu/adamo dar/pdfiles/papers/finfirm09.pdf (accessed on 4 December 2020).

54. IPEV. Valuation Guidelines. 2018. Available online: http://www.privateequityvaluation.com/Valuation-Gui delines (accessed on 4 December 2020).

55. Cumming, D.J.; Schwienbacher, A. FinTech venture capital. Corp Gov. 2019, 26, 374-389. [CrossRef]

56. Saeterboe, M. FinTech Valuation: Is Real Option Valuation a Suitable Approach to Value US Listed FinTech Companies? Master Thesis, Universidade Catolica Portuguesa, Lisbon, Portugal, 2019. Available online: http://hdl.handle.net/10400.14/29147 (accessed on 4 December 2020).

57. Fazekas, B. Value-creating uncertainty-A real options approach in venture capital. Finan. Econ. Re. 2016, 15, 151-166.

58. Wafi, A.S.; Hassan, H.; Mabrouk, A. Fundamental Analysis Models in Financial Markets-Review Study. Proc. Econ. Financ. 2015, 30, 939-947. [CrossRef]

59. Brandl, B.; Hornuf, L. Where did FinTechs Come from, and Where do They Go? The Transformation of the Financial Industry in Germany after Digitalization. 2017. Available online: https://ssrn.com/abstract=3036555 (accessed on 4 December 2020).

60. Demyanova, E.A. The Topical Issues of Valuation of Companies Under the Conditions of FinTech. Strat. Dec. Risk Manag. 2018, 1, 88-103.

61. European Banking Authority. Discussion Paper on the EBA's Approach to Financial Technology (FinTech). European Banking Authority, 4 August 2017. Available online: https:/eba.europa.eu/sites/default/documents/files/documents/10180/1919160/7a1b9cda-10ad-4315-91ce-d 798230ebd84/EBA\%20Discussion\%20Paper\%20on\%20Fintech\%20\%28EBA-DP-2017-02\%29.pdf?retry=1 (accessed on 4 December 2020).

62. Mention, A. The Future of FinTech. Res. Technol. Manag. 2019, 62, 59-63. [CrossRef]

63. Arner, D.W.; Buckley, R.P.; Zetzsche, D.A.; Veidt, R. Sustainability, FinTech and financial inclusion. Eur. Bus Org. Law Re. 2020, 21, 7-35. [CrossRef] 
64. Moro-Visconti, R. Cash Flow Forecasting of Debt-Free Startups. Working Paper. 2020. Available online: https: //www.researchgate.net/publication/340574298_Cash_flow_forecasting_of_debt-free_startups (accessed on 4 December 2020).

65. Patev, P.; Petkov, K. Simple Valuation Methods: Franchise Value Approach. 2018. Available online: https://www.researchgate.net/publication/331275721 (accessed on 4 December 2020).

66. Damodaran, A. The Dark Side of Valuation; Pearson Education: London, UK, 2018.

67. Stiglitz, J.E.; Weiss, A. Credit Rationing in Markets with Imperfect Information. Am. Econ. Rev. 1981, 71, 393-410.

68. Shiller, R. Irrational Exuberance; Princeton University Press: Princeton, NJ, USA, 2016.

69. Cervellati, E. Analysts' Distorted Valuation of Hi-Tech Stocks. Corp Ownersh. Control. 2012, 10, $380-395$. [CrossRef]

70. Zetzsche, D.A.; Buckley, R.P.; Arner, D.W.; Barberis, J.N. From FinTech to TechFin: The Regulatory Challenges of Data-Driven Finance. NYU J. Law Bus. 2018, 14, 393-446. [CrossRef]

71. Deng, X.; Huang, Z.; Cheng, X. FinTech and sustainable development: Evidence from China based on P2P data. Sustainability 2019, 11, 6434. [CrossRef]

72. Ashta, A.; Biot-Paquerot, G. FinTech evolution: Strategic value management issues in a fast changing industry. Strat. Chang. 2018, 27, 301-311. [CrossRef]

73. Al Hammadi, T.; Nobanee, H. FinTech and Sustainability: A Mini-Review. 2019. Available online: https://www.researchgate.net/publication/338285271 (accessed on 4 December 2020).

74. Stulz, R. FinTech, BigTech, and the Future of Banks. J. App. Corp Financ. 2019, 31, 86-97. [CrossRef]

75. Gomber, P.; Koch, J.; Siering, M. Digital Finance and FinTech: Current research and future research directions. J. Bussiness Econ. 2017, 87, 537-580. [CrossRef]

76. Cen, T.; He, R. FinTech, Green Finance and Sustainable Development. Adv. Soc. Sci. Educ. Hum. 2018, 291, 222-225.

77. Goldstein, I.; Jiang, W.; Karolyi, G.A. To FinTech and Beyond. Rev. Financ. Stud. 2019, 32, 1647-1661. [CrossRef]

78. Financial Stability Board, Financial Stability Implications from FinTech, 27 June 2017. Available online: https://www.fsb.org/wp-content/uploads/R270617.pdf (accessed on 4 December 2020).

79. O'Leary, L.; Hauman, M. Regulatory Implications of ESG Investment. J. Financ. Transf. 2020, 51, $163-171$.

80. Salampasis, D.; Mention, A. FinTech: Harnessing Innovation for Financial Inclusion. In Handbook of Blockchain, Digital Finance, and Inclusion; Chuen, D.L.K., Deng, R., Eds.; Academic Press: Cambridge, MA, USA, 2018; Volume 2, pp. 451-461.

81. Pantielieieva, N.S.; Krynytsia, M.; Khutorna, L. Potapenko, FinTech, Transformation of Financial Intermediation and Financial Stability, International Scientific-Practical Conference Problems of Infocommunications; Science and Technology (PIC S\&T): Kharkiv, Ukraine, 2018; pp. 553-559.

82. Azarenkova, G.; Shkodina, I.; Samorodov, B.; Babenko, M.; Onishchenko, I. The influence of financial technologies on the global financial system stability. Invest. Manag. Financ. Innov. 2018, 15, 229-238. [CrossRef]

83. Fenwick, M.; Vermeulen, E.P.M. Banking and Regulatory Responses to Fintech Revisited-Building the Sustainable Financial Service 'Ecosystems' of Tomorrow. Singap. J. Legal Stud. 2020, 165-189. [CrossRef]

84. Blakstad, S.; Allen, R. FinTech Revolution; Palgrave Macmillan: Cham, Switzerland, 2018.

Publisher's Note: MDPI stays neutral with regard to jurisdictional claims in published maps and institutional affiliations.

(C) 2020 by the authors. Licensee MDPI, Basel, Switzerland. This article is an open access article distributed under the terms and conditions of the Creative Commons Attribution (CC BY) license (http://creativecommons.org/licenses/by/4.0/). 